\author{
ACTA MYCOLOGICA \\ Vol. 48 (1): 123-131 \\ 2013
}

DOI: $10.5586 / \mathrm{am} .2013 .014$

\title{
The occurrence of Amanita strobiliformis (Paulet ex Vittad.) Bertill. in Szczecin and its distribution in Poland
}

\author{
STEFAN FRIEDRICH \\ Department of Botany and Plant Protection, West Pomeranian University of Technology in Szczecin \\ ul. Słowackiego 17, PL-71-434 Szczecin, Stefan.Friedrich@zut.edu.pl
}

Friedrich S.: The occurrence of Amanita strobiliformis (Paulet ex Vittad.) Bertill. in Szczecin and its distribution in Poland. Acta Mycol. 48 (1): 123-131, 2013

Results of long-term research into the occurrence of Amanita strobiliformis in Szczecin are presented. Five new localities of the species are described and its distribution in Poland is discussed.

Key words: Amanitaceae, urban mycobiota, fungal phenology, chorology

\section{INTRODUCTION}

Amanita strobiliformis is a thermophilous and calciphilous species that forms symbiosis primarily with deciduous trees, mostly of the genera Fagus, Quercus, Betula and Tilia, less frequently with coniferous trees: Pinus and Picea. It is widespread and occurs in Australia, East and Central Asia, North America, North Africa and Europe. In Europe, it occurs more frequently in the south and its northern limit reaches southern Scandinavia but does not exceed $60^{\circ}$ latitude (Krieglsteiner 2003).

Amanita strobiliformis was thought to be extinct in Poland (Wojewoda, Ławrynowicz 1992) as it was initially known only from Tomaszów Lubelski (Błoński 1896) and from Elbląg (Nitardy 1904). The herbarium specimen from the Elbląg locality is not available and Skirgiełło (1972) suggested it might have been a determination error. The species has been recorded by several authors at scattered localities throughout Poland since the mid 1990s and is included as a rare species (R) on the current red list of fungi (Wojewoda, Ławrynowicz 2006).

The occurrence of Amanita strobiliformis in Szczecin between 1997 and 2012 is characterized below. Five new localities recorded in the years 2007-2011 are presented and the current distribution of the species in Poland is discussed. 


\section{MATERIALS AND METHODS}

Amanita strobiliformis was reported from the Dendrological Garden in Szczecin where it was first recorded in 1997 (Friedrich, Orzechowska 2002; Friedrich 2011). It was the sixth locality of the species in Poland. Both the locality and the Dendrological Garden was systematically observed after the first record for the occurrence of mycobiota. Fruit bodies of Amanita strobiliformis were counted every year and the geographical position of the occurrence sites was determined in the field and mapped. A spread of Amanita strobiliformis from the initial site and an increased range were recorded. Fruit bodies occurred only at one site covering an area of ca. $20 \mathrm{~m}^{2}$ in the first four years (site 1). They were also recorded outside site 1 in the following years and occurred at a total of twelve field sites throughout the study. They grew at nine sites in the Dendrological Garden in Szczecin and its immediate vicinity in the final year (2012). At present the occurrence area of Amanita strobiliformis resembles a triangle $560 \times 580$ $\times 350 \mathrm{~m}$ and is regarded as one locality comprising twelve sites in the discussion. The farthest points from site 1 are $180 \mathrm{~m}$ westwards, $410 \mathrm{~m}$ north-eastwards and $350 \mathrm{~m}$ eastwards. The distance between adjacent sites of this vast locality is between 20 and $50 \mathrm{~m}$.

\section{THE LOCALITY IN THE DENDROLOGICAL GARDEN IN SZCZECIN}

The locality: characteristic features. Site 1 of the locality where Amanita strobiliformis has fruited every year since 1997 is in the south-east corner of the Dendrological Garden and is surrounded by a small stone wall on three sides. The wall borders on an asphalt park alleyway, a street Słowacki and the premises of the West Pomeranian University of Technology (formerly Agricultural Academy).

An old tree stand which remains after a former cemetery stand consists of Quercus robur, Tilia cordata, Acer pseudoplatanus, Platanus $\times$ hispidus and Pseudotsuga menziesii. Fruit bodies of $A$. strobiliformis occurred between two oaks and a lime tree. The stand belongs to forest communities of the class Querco-Fagetea but only Aegopodium podagraria, Ficaria verna and the moss Plagiomnium undulatum were recorded. The forest floor is not dense. As well as the above species, it mostly comprises species of synanthropic communities of the class Artemisietea (Alliaria petiolata, Anthriscus sylvestris, Chaerophyllum temulum, Galium aparine, Geranium robertianum, Geum urbanum, Viola odorata) and Stelarietea (Lapsana communis, Veronica hederifolia) and species of meadow communities of the class Molinio-Arrhenatheretea (Achillea millefolium, Arrhenatherum elatius, Bellis perennis, Ceratium holosteoides, Dactylis glomerata, Festuca pratensis, Poa pratensis, Taraxacum officinale, Trifolium pratense, T. repens). These species are accompanied by Allium vineale, Hedera helix, Moechringia trinervia, Plantago major, Poa annua and Veronica chamaedrys. The forest floor is mown, usually twice every year. This sometimes contributes to the destruction of fungal fruit bodies. The litter of varying thickness and single specimens of few species of herbaceous plants and moss species occur at other sites outside site 1 on the lawn in the West Pomeranian University of Technology. 


\section{RESULTS}

Fruit bodies of 31 species of fungi were recorded at site 1 during the study period. Saprotrophs prevail among them. The mycobiota of the site is formed by Agaricus arvensis, $A$. augustus, $A$. bisporus, $A$. xanthodermus, Amanita strobiliformis, Baeospora myosura, Boletus luridus, Strobilurus tenacellus, Conocybe semiglobata, C. tenera, Daedalea quercina, Exidia truncata, Hypholoma fasciculare, Inocybe erubescens, I. fastigiata, I. geophylla, I. griseolilacina, Lepiota cristata, Lepista nuda, Marasmius rotula, Mycena filopes, Mycena galericulata, Mycena vitilis, Panaeolus foenisecii, Pluteus atricapillus, Russula aeruginea, Scleroderma areolatum, S. verrucosum, Trametes versicolor, Xerocomus chysentheron, Vuilleminia comedens. Sixteen further species were recorded at other sites where Amanita strobiliformis occurs: Amanita phalloides, Coprinellus disseminatus, C. micaceus, Exidia plana, Fomes fomentarius, Ganoderma applanatum, Gloeophyllum sepiarium, Helvella acetabulum, H. crispa, Lepiota aspera, Marasmius oreades, Peniophora quercina, Russula amoenolens, $R$. cyanoxantha, Tricholoma scalpturatum, Xerula radicata.

Fruit bodies of Amanita strobiliformis usually grew near trees: Fagus sylvatica, Quercus robur, Tilia cordata, Acer (platanoides, pseudoplatanus, negundo), Betula pendula, and shrubs Corylus avellana and Padus serotina within the entire occurrence area. Fruit bodies occurred exclusively near Acer platanoides at two sites. The species has not been previously reported as its symbiont by other authors. No other trees were located within ca. $35 \mathrm{~m}$.

The majority of the twelve occurrence sites of Amanita strobiliformis at the locality lie along the margin of the Dendrological Garden and the side of the street (Słowackiego) adjacent to the Park Kasprowicza park. Fruit bodies grow here on anthropogenic urban soils with $\mathrm{pH}$ ranging between 7.0 and $7.3 \mathrm{pH}_{\mathrm{KCl}}(\mathrm{Niedźwiecki}$

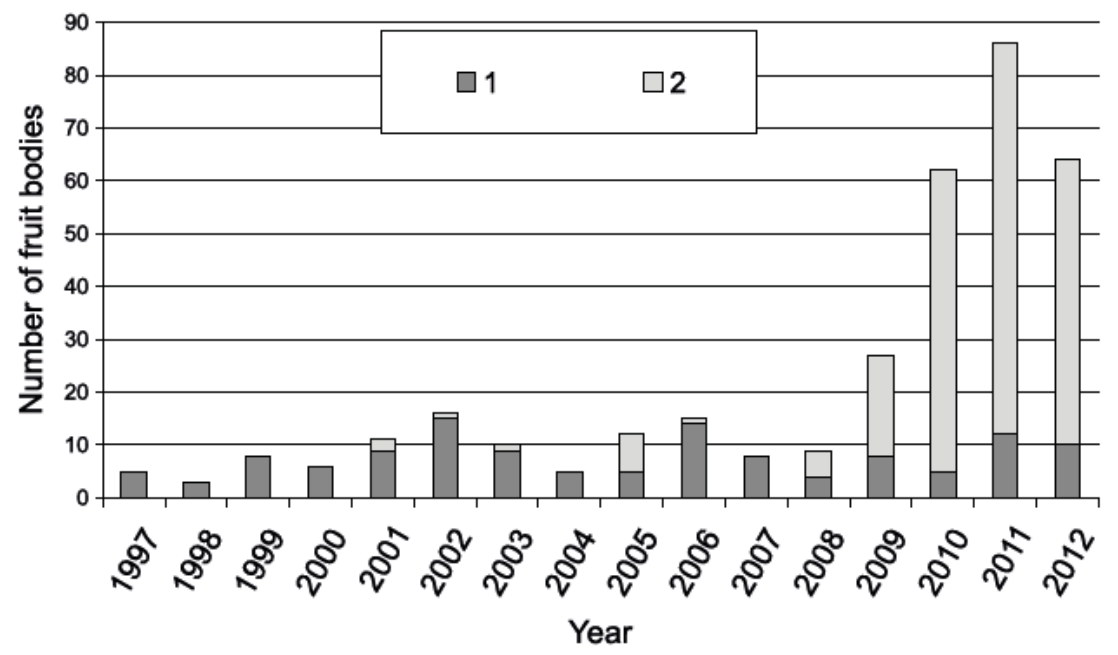

Fig. 1. The number of fruit bodies of Amanita strobiliforis in the Dendrological Garden, Szczecin, in individual years of the study: 1 - site 1 of the locality, 2 - other sites of the locality. 


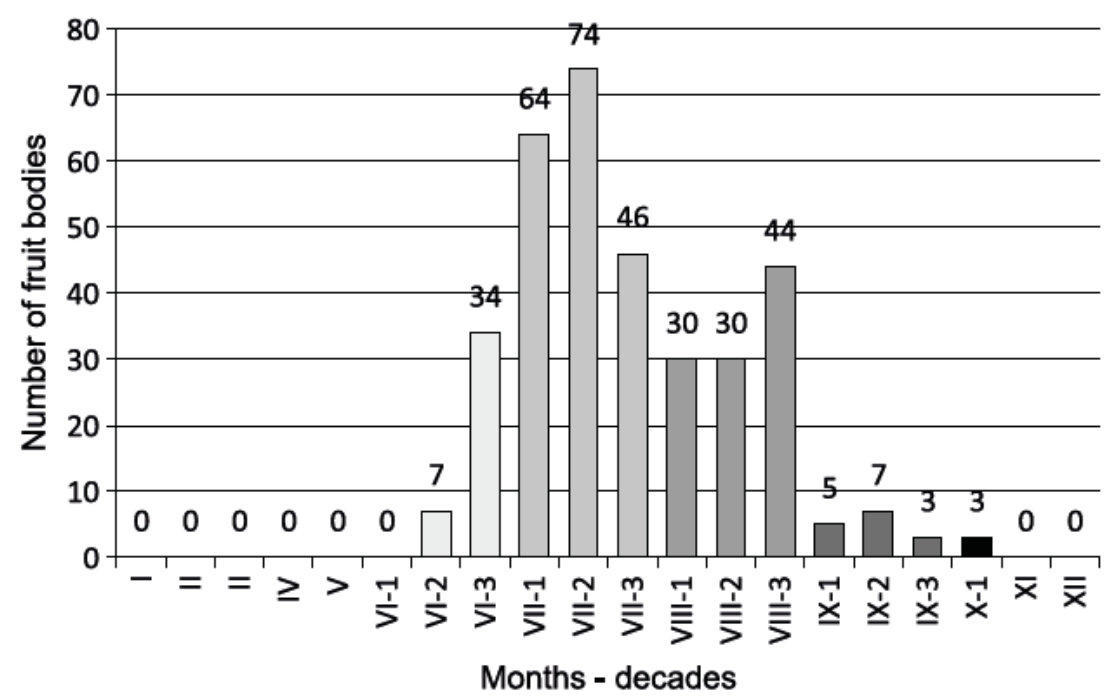

Fig. 2. Phenology of Amanita strobiliformis in the Dendrological Garden, Szczecin: the number of fruit bodies in individual periods of ten days for each month.

et al. 2004). An increased contamination with heavy metals is recorded in these soils ( $1^{\text {st }}$ degree for cadmium, lead and copper and $2^{\text {nd }}$ degree for zinc).

Phenology of Amanita strobiliformis. A total of between three and eighty six fruit bodies were recorded at all of the sites at this locality in individual years (Fig. 1). Altogether 347 fruit bodies of Amanita strobiliformis developed from 1997 until 2012 of which $61 \%$ developed in the final three years of the study. $A$. strobiliformis occurred every year only at the first site. Between three and fifteen fruit bodies, a total of 126 , were observed in individual years. This is $36 \%$ of the total number of fruit bodies produced during the observation period spanning 16 years. A total of 221 fruit bodies were observed at the remaining sites over a period of ten years. From one to forty eight fruit bodies occurred at these sites. They occurred at them over a period of one to seven years (most frequently for three to four years).

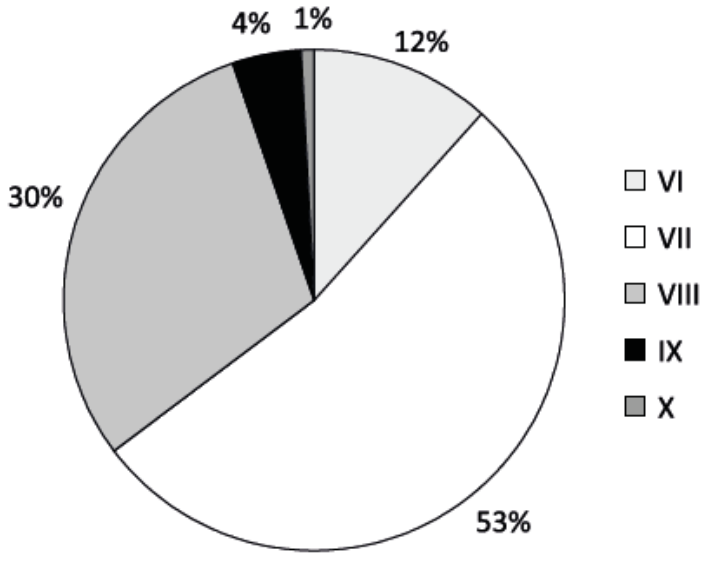

Fig. 3. The contribution of fruit bodies of Amanita strobiliformis occurring in the Dendrological Garden, Szczecin, in individual months during the study period. 
More fruit bodies matured in favourable weather conditions, especially 2010-2011, and the period of their full development, from the development of the primordium to the initial phase of drying or dying, lasted from six to nine days, usually seven days. Many fruit bodies dried at different stages of development and did not produce spores in hot years with a rain-free summer period, especially in 2006. The period of the full development observed in few fruit bodies lasted then even 12 days. First fruit bodies

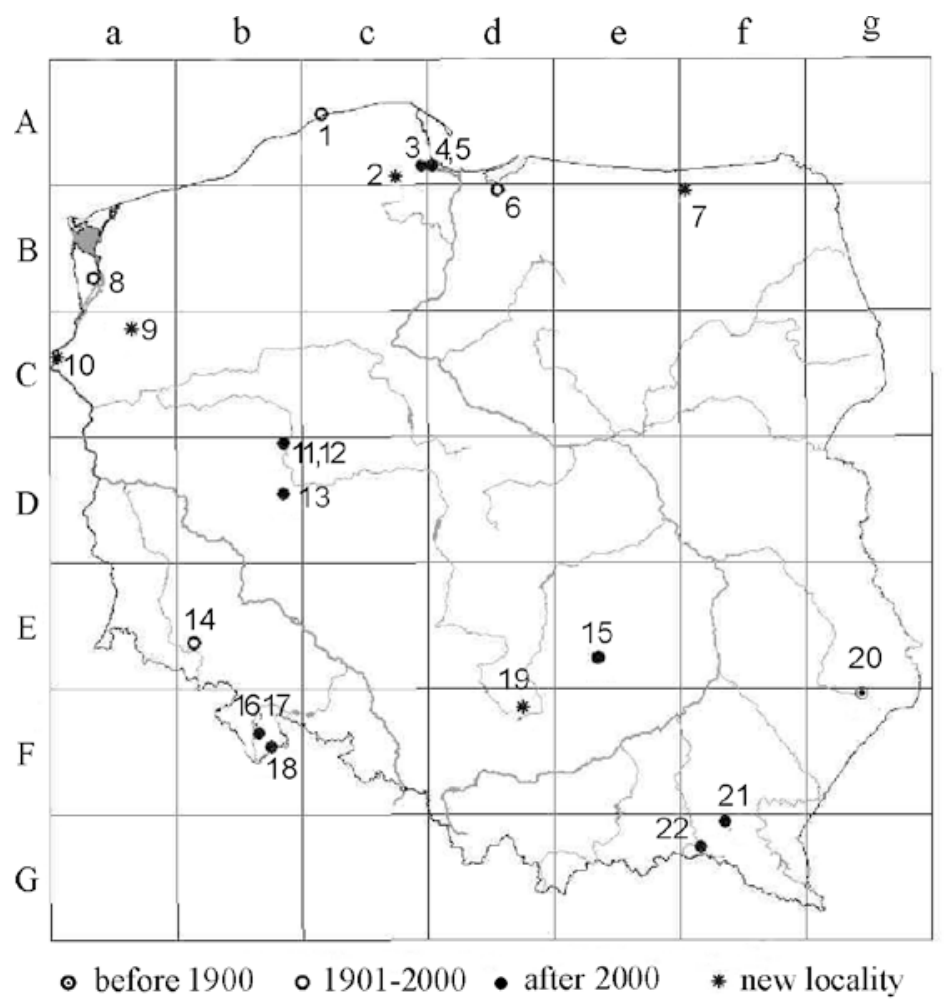

Fig. 4. Localities of Amanita strobiliformis in the ATPOL grid square system: 1 - Ac-41 Słowiński National Park, Czołpino (Bujakiewicz, Lisiewska 1983), 2 - Ac-97 - Ostrzyce (new locality), 3 - Ac-89 - Gdańsk (Wilga 2004, 2005), 4 - Ad-80 - Gdańsk, ul. Narutowicza (Wilga 2004, 2005), 5 - Ad- 80 - Gdańsk, Abrahama and Siemiradzkiego (Kujawa, Gierczyk 2010), 6 - Bd-05 - Elbląg (Nitardy 1904), 7 - Bf-00 - Węgorzewo (new locality), 8 - Ba-73 - Szczecin, Dendrological Garden (Friedrich, Orzechowska 2002), 9 - Ca-16 - Przelewice (new locality), 10 - Ca-30 - Bielinek (new locality), 11 - Db-08 - Poznań, Botanical Garden, Adam Mickiewicz University (Lisiewska, Mikołajczak 1998), 12 - Db-08 - Poznań, Sołacki Park (Kudławiec 2008, 2009, 2010, 2011), 13 - Db-48 - Dezydery Chłapowski Landscape Park (Kujawa 2009), 14 - Eb-61 - Góry Kaczawskie Mts, „Góra Miłek” reserve (Narkiewicz 2000), 15 - Ee-73 Góry Świętokrzyskie Mts, Góra Malik (Łuszczyński 2002, 2007, 2008), 16 - Fb-36 - Kotlina Kłodzka basin, Góra Bielica (Kujawa 2005), 17 - Fb-36 - Kotlina Kłodzka basin, Góra Słupiec (Kujawa 2005), 18 - Fb-47 - Kotlina Kłodzka basin, Bolesławów (Kujawa 2005), 19 - Fd-17 Giebło (new locality), 20 - Fg-04 - Tomaszów Lubelski (Błoński 1896), 21 - Gf-03 - Miejsce Piastowe (Hreczka 2010), 22 - Gf-21 - Olchowiec (Kujawa, Gierczyk 2010). 
were observed on the $13^{\text {th }}$ June (2007) at the earliest and the last ones on the $7^{\text {th }}$ October (2008) at the latest during the study period. The fruiting peak occurred in July when 53\% of fruit bodies were recorded and in August - 30\% (Figs 2, 3). The longest fruiting period lasting three months was observed in 2011 (from the $5^{\text {th }}$ July until the $5^{\text {th }}$ October) and in 2012 (from $18^{\text {th }}$ June until $18^{\text {th }}$ September). Some fruit bodies grew in pairs. This was observed for 56 fruit bodies, i.e. ca. $16 \%$ of their total number.

Amanita strobiliformis is endangered by slugs feeding on its fruit bodies. A threat is also posed by people who thoughtlessly destroy many fungal species. A total of 108 fruit bodies (ca. 31\%) were destroyed during the study period: 56 were eaten by slugs and 52 were destroyed by people. Slugs posed a smaller risk in dry years when heavy blackening of fruit bodies by insect larvae was observed more frequently.

New localities. Five new localities of Amanita strobiliformis scattered across Poland were recorded between 2007 and 2011. Three are in various beech communities while the other two are in a city park and a dendrological garden. The localities are characterized below in the order they were reported. They are positioned in relation to the nearest village or town in the ATPOL grid (Zając 1978) modified for mycology by Wojewoda (2000), in geographic mesoregions (Kondracki 2002) and in voivodeships. The numbering of localities corresponds to the numbering in Figure 4 which also presents localities known from the literature.

Przelewice (Fig. 4 - locality 9). ATPOL Ca-16, Równina Pyrzycko-Stargardzka plain (313.31), West Pomeranian voivodeship. The locality of Amanita strobiliformis in Przelewice was recorded during long-term systematic research into the mycobiota of the Dendrological Garden. A total of 14 fruit bodies were observed over three years $(18.06 .2007,19.07 .2007,08.07 .2009,10.08 .2009,12.07 .2010,20.07 .2011)$. They grew at four different sites less than a hundred meters apart. The majority of fruit bodies grew near Fagus sylvatica and Fraxinus exscelsior, and two near Betula lutea, Prunus serotina and Malus sp. Six fruit bodies were destroyed by people despite the monitoring in the Garden.

Bielinek (Fig. 4 - locality 10). ATPOL Ca-30, Pojezierze Myśliborskie lake district (314.41), West Pomeranian voivodeship. Amanita strobiliformis was observed only once (20.09.2008) at the locality in the Bielinek xerothermic reserve, ca $2 \mathrm{~km}$ NE of Bielinek. Three fruit bodies grew under Fagus sylvatica by a path along the margin of Galio odorati-Fagetum which covers a gentle south-facing slope.

Węgorzewo (Fig. 4 - locality 7). ATPOL Fb-00, Kraina Wielkich Jezior Mazurskich (Great Masurian Lakes Region, 842.83), Warmia and Mazury voivodeship. This locality of Amanita strobiliformis was recorded during a holiday stay in Węgorzewo on 27.07.2009. It is in the Helwing Park, near Generała J. Bema street and a few meters from a park alleyway. Three developing fruit bodies grew on a lawn near Tilia cordata, just outside the reach of the crown.

Giebło (Fig. 4 - locality 19). ATPOL Df-17, Wyżyna Częstochowska upland (341.31), Silesian voivodeship. The locality of Amanita strobiliformis was recorded in the Las Niwiski forest in Giebło village near Ogrodzieniec, ca. $6 \mathrm{~km} \mathrm{NW}$ of the Pilica river. Fagus sylvatica-Cruciata glabra forest community occurs at the locality. One fruit body was recorded on the soil under Fagus sylvatica in September 2008 and 2009 (leg. et det. D. Karasiński). One fruit body was destroyed by mushroom pickers. 
Ostrzyce (Fig. 4 - locality 2). ATPOL Ac-97, Pojezierze Kaszubskie lake district (314.51), Pomeranian voivodeship. Amanita strobiliformis was observed in the Ostrzycki Las reserve, ca. $10 \mathrm{~km}$ SW of Kartuzy, in Fagus sylvatica-Cypripedium calceolus, on brown rendzina developed on a layer of calcareous mud. Five fruit bodies at different stages of development grew on the soil under Fagus sylvatica on 14.08.2010 (leg. et det. D. Karasiński).

\section{DISCUSSION}

Amanita strobiliformis was recorded in Poland only at five localities in the $20^{\text {th }}$ century. It was noted for the first time after a period spanning a few decades in 1967 (Bujakiewicz, Lisiewska 1983). It is not clear whether the species did not occur (did not develop fruit bodies) in Poland or whether it was not observed for various reasons for such a long time in the $20^{\text {th }}$ century. Some 90 localities were recorded in Germany (Krieglsteiner 1991) in similar physiogeographic conditions (between $50^{\circ}$ and $55^{\circ}$ latitude) in the same period.

One of the reasons for this may be that mycological research in Poland was mostly conducted in natural forests, national and landscape parks, nature reserves while this species often occurs in parks and anthropogenic areas in Poland. Descriptions of localities of Amanita strobiliformis in Poland available in the literature show that half of the localities are in park-like anthropogenic tree patches, e.g. the Botanical Garden in Poznań, Dendrological Gardens in Szczecin and Przelewice, city parks in Poznań, Węgorzewo and Gdańsk. Fruit bodies usually occur under Fagus sylvatica, less frequently under Quercus sp., Tilia sp. and Betula pendula. As fruit bodies develop in parks, in noticeable places, they are destroyed by people, as noted by authors such as Wilga (2005) and Kudławiec (2008-2011).

At present a total of 22 localities, including the new localities described here, in 19 ATPOL 10x10 km squares are known in Poland (Fig. 4). Approximately half of them have been reported by non-professionals in the last ten years. Amateur fungal groups importantly contribute to the recognition of the distribution of fungi in Poland, also rare and threatened species.

Fruit bodies were produced between June and October at the localities in Poland. This was also the period when fruit bodies were observed at the locality in the Dendrological Garden in Szczecin over a period of 16 years. A detailed seasonal rhythm of fruit body production at this locality is similar to the results of studies in Germany (Baden-Württembergs) but the fruiting peak begins a month earlier (Krieglsteiner 2003). One-time data on the occurrence of Amanita strobiliformis which usually produced only single fruit bodies (1-3) are reported from the majority of Polish localities. The most abundant localities where Amanita strobiliformis produces annually from over ten to over fifty fruit bodies are the Dendrological Garden in Szczecin and the Park Sołacki park in Poznań, where a total of over 50 fruit bodies were observed over four consecutive years (Kudławiec 2008, 2009, 2010, 2011).

Acknowledgements. The author thanks Dr. Dariusz Karasiński for providing information on two new localities of Amanita strobiliformis. 


\section{REFERENCES}

Błoński F. 1896. Przyczynek do flory grzybów Polski. Pamiętn. Fizyjogr. 4 (III): 63-93.

Bujakiewicz A., Lisiewska M. 1983. Mikoflora zbiorowisk roślinnych Słowińskiego Parku Narodowego. Bad. Fizjogr. Pol. Zach. Seria B - Bot. 34: 49-77.

Friedrich S. 2011. Charakterystyka występowania muchomora szyszkowatego Amanita strobiliformis (Paulet ex Vittad.) Bertillon w Szczecinie. Konferencja Naukowa. Polskie tradycje użytkowania grzybów oraz ich ochrony wkładem do europejskiego dziedzictwa kultury. Łódź 3-5.11.2011. Wyd. Uniw. Łódzkiego, Łódź: 45-46.

Friedrich S., Orzechowska M. 2002. Macromycetes w środowisku miejskim Szczecina. Bad. Fizjogr. Pol. Zach. Seria B, Bot. 51: 7-30.

Hreczka A. 2010. Amanita strobiliformis. ID 169498. W: Snowarski M. Atlas grzybów Polski. Rejestr gatunków grzybów chronionych i zagrożonych. http://www.grzyby.pl./rejestr-grzybow-chronionychi-zagrozonych.htm

Kondracki J. 2002. Geografia regionalna Polski. PWN, Warszawa.

Krieglsteiner G.J. 1991. Verbreitungsatlas der Grosspilze Deutschlands (West). Verlag Eugen Ulmer.

Krieglsteiner G.J. (Hrsg.). 2003. Die Grosspilze Baden-Württembergs. B. 4. Ständerpilze: Blätterpilze II. Ver. Eugen Ulmer, Stuttgart.

Kudławiec B. 2008. Amanita strobiliformis. ID 114510. W: Snowarski M. Atlas grzybów Polski. Rejestr gatunków grzybów chronionych i zagrożonych. http://www.grzyby.pl./rejestr-grzybow-chronionychi-zagrozonych.htm

Kudławiec B. 2009. Amanita strobiliformis. ID 156115. W: Snowarski M. Atlas grzybów Polski. Rejestr gatunków grzybów chronionych i zagrożonych. http://www.grzyby.pl./rejestr-grzybow-chronionychi-zagrozonych.htm

Kudławiec B. 2010. Amanita strobiliformis. ID 195538. W: Snowarski M. Atlas grzybów Polski. Rejestr gatunków grzybów chronionych i zagrożonych. http://www.grzyby.pl./rejestr-grzybow-chronionychi-zagrozonych.htm

Kudławiec B. 2011. Amanita strobiliformis. ID 195538. W: Snowarski M. Atlas grzybów Polski. Rejestr gatunków grzybów chronionych i zagrożonych. http://www.grzyby.pl./rejestr-grzybow-chronionychi-zagrozonych.htm

Kujawa A. 2005. „Rejestr gatunków grzybów chronionych i zagrożonych” - nowa forma gromadzenia danych mikologicznych pochodzących od amatorów. Podsumowanie roku 2005. Przegląd Przyrodniczy 16 (3-4): 17-52

Kujawa A. 2009. Macrofungi of wooded patches in the agricultural landscape. I. Species diversity. Acta Mycol. 44 (1): 49-75.

Kujawa A., Gierczyk R. 2010. Rejestr gatunków grzybów chronionych i zagrożonych w Polsce. III. Wykaz gatunków przyjęty do rejestru w roku 2007. Przegląd Przyrodniczy 21 (1): 8-53.

Lisiewska M., Mikołajczak M. 1998. Ogród Botaniczny Uniwersytetu im. A. Mickiewicza w Poznaniu jako środowisko przyrodnicze grzybów wielkoowcnikowych. Bad. Fizjogr. Pol. Zach. Seria B, Bot. 47: 7-44.

Łuszczyński J. 2002. Preliminary red list of Basidiomycetes in the góry Świętokrzyskie Mts (Poland). Polish Bot. J. 47 (2): 183-193.

Luszczyński J. 2007. Diversity of basidiomycetes in various ecosystems of the Góry Świetokrzyskie Mts. Monogr. Bot. 97: 1-218.

Luszczyński J. 2008. Basidiomycetes of the Góry Świetokrzyskie Mts a checklist. Wyd. UH-P, Kielce.

Narkiewicz C. 2000. Borowik szatański Boletus satanas i muchomor szyszkowaty Amanita strobiliformis w rezerwacie „Góra Miłek” w Górach Kaczawskich. Przyr. Sudetów Zach. 3: 69-72.

Niedźwiecki E., Meller E., Malinowski R., Sammel A., Kruczyńska J. 2004. Mniszek pospolity (Taraxacum officinale) jako bioindykator zanieczyszczenia metalami ciężkimi gleb miejskich Szczecina. Folia Univ. Agric. Stetin. Agricultura 242 (98): 103-108.

Nitardy E. 1904. Die Kryptogamenflora des Kreises Elbing, Hedwigia 43: 314-342.

Skirgiełło A. 1972. Materiały do poznania rozmieszczenia geograficznego grzybów wyższych w Europie. IV. Acta Mycol. 8 (2): 191-218.

Wilga M. 2004. Chronione i zagrożone grzyby wielkoowocnikowe (macromycetes) Trójmiejskiego Parku Krajobrazowego (Pomorze Gdańskie). Przegląd Przyrodniczy 15 (1-2): 3-17. 
Wilga M.S. 2005. Muchomor szyszkowaty Amanita strobiliformis (Paulet ex Vittad.) Bertillon w Gdańsku. Chrońmy Przyrodę Ojcz. 61 (5): 93-100.

Wojewoda W. 2000. (ed.) Atlas of the geographical of fungi in Poland. 1. W. Szafer Institute of Botany, Polish Academy of Sciences, Kraków.

Wojewoda W., Lawrynowicz M. 1992. Red list of threatened macrofungi in Poland. (In:) K. Zarzycki, W. Wojewoda, Z. Heinrich (eds). List of threatened plants in Poland, 2 ed. W. Szafer Institute of Botany, Polish Academy of Sciences, Kraków: 27-56.

Wojewoda W., Ławrynowicz M. 2006. Red list of the macrofungi in Poland. (In:) Z. Mirek, K. Zarzycki, W. Wojewoda, Z. Szelagg (eds). Red list of plants and fungi in Poland. 3 ed. W. Szafer Institute of Botany, Polish Academy of Sciences, Kraków: 53-70.

Zając A. 1978. Założenia metodyczne „Atlasu rozmieszczenia roślin naczyniowych w Polsce”. Wiad. Bot. 22 (3): $145-155$.

Występowanie muchomora szyszkowatego Amanita strobiliformis (Paulet ex Vittad.) Bertill. w Szczecinie na tle jego rozprzestrzenienia w Polsce

\section{Streszczenie}

W pracy przedstawiono wyniki 16-letnich (1997-2012) badań nad występowaniem muchomora szyszkowatego Amanita strobiliformis w Ogrodzie Dendrologicznym w Szczecinie. W 12 punktach tego rozległego stanowiska wyrosło łącznie 347 owocników, z czego aż około 36\% w punkcie 1, w którym owocniki obserwowano rokrocznie (Fig. 1). W pozostałych punktach owocniki wyrastały najczęściej przez 3-4 lata (od 1 roku do 7 lat). Najwcześniej owocniki obserwowano 13 czerwca, a najpóźniej - 7 października. Szczyt owocnikowania przypadał w lipcu, kiedy stwierdzono 53\% owocników i sierpniu - 30\% (Figs 2, 3). Najdłuższy okres owocnikowania trwający 3 miesiące, wystąpił w latach 2011 i 2012.

Przedstawiono również 5 nowych stanowisk muchomora szyszkowatego stwierdzonych w różnych regionach kraju, w latach 2007-2011. Łącznie z tymi nowymi stanowiskami, w Polsce znane są obecnie 22 stanowiska zlokalizowane w 19 kwadratach ATPOL $10 \times 10$ km (Ryc. 4). 